\title{
INTERCAMBIO DE CARGA Y EMISIÓN ELECTRÓNICA EN LA COLISIÓN DE IONES CON SUPERFICIES CARBONADAS
}

Vanessa Alexandra Quintero Riascos

valexa85@gmail.com

Doctorado en Física

Lugar de defensa: Facultad de Bioquímica y Ciencias Biológicas de la Universidad Nacional del Litoral. Director: Fernando Bonetto.

Co-directora: Edith Goldberg

Fecha de defensa: 17 de mayo de 2019

\section{RESUMEN}

Se analiza desde el punto de vista experimental y teórico la formación de iones positivos y negativos durante el proceso de intercambio de carga en colisiones de protones con un sustrato metálico de $\mathrm{Cu}$ (111) y con diferentes espesores de recubrimientos de $C_{60}$ depositados sobre $\mathrm{Cu}$ (111). Por el lado experimental, se utilizó la técnica de caracterización superficial LEIS (Low energy ion scattering) para determinar el estado de carga de los proyectiles luego de la colisión de los mismos sobre estas superficies -blanco. Se analizó un amplio rango de energías de entrada del proyectil y se estudiaron dos geometrías diferentes de colisión: para ángulos de entrada/salida 45/90 y 67.5\%/67.5 medidos con respecto a la superficie- blanco. Para lograr entender los procesos físicos que determinan el estado final de carga de los proyectiles luego de colisionar con las superficies descriptas, se realizaron cálculos teóricos aplicando un formalismo mecánico cuántico basado en primeros principios para describir las fracciones de carga finales en los sistemas analizados.

Particularmente para el sistema $\mathrm{H} / \mathrm{Cu}$ (111), de la comparación directa de los resultados experimentales obtenidos para ambas configuraciones geométricas, se observa una dependencia con la energía muy sensible a los ángulos de entrada/salida, aun cuando las magnitudes de las fracciones de carga no se alteran sustancialmente.

Las diferencias importantes entre las mediciones y la teoría; y el análisis de tiempos característicos indican que la trayectoria de entrada del proyectil juega un papel preponderante en el problema de transferencia de carga en este sistema.

Respecto a los experimentos de transferencia de carga en colisiones de baja energía del $\mathrm{H}^{+}$con un recubrimiento grueso (3 monocapas) de $\mathrm{C}_{60} / \mathrm{Cu}$ (111) se encontró que el porcentaje de iones totales retrodispersados aumenta con la energía de incidencia y, contrariamente a lo que ocurre en el sistema $\mathrm{H} / \mathrm{Cu}$ (111), la fracción de iones positivos es mayor que la de negativos en prácticamente todo el rango de energía estudiado. Tanto las magnitudes de las fracciones de carga como su dependencia con la energía 
son muy similares a las obtenidas en la dispersión de protones por HOPG, sistema previamente estudiado en nuestro grupo. Los cálculos teóricos de la fracción de iones sobre el recubrimiento grueso de $\mathrm{C}_{60}$ muestran un buen acuerdo con el experimento tanto para el caso de 45\%/90 como para el de geometría especular. El análisis de los tiempos característicos indica claramente que existe una "pérdida de memoria" del estado de carga del proyectil para distancias pequeñas proyectil-superficie blanco que conduce a que el estado de carga final del proyectil se defina en la trayectoria de salida. De este modo se explica el mejor acuerdo entre resultados teóricos y experimentales para la geometría 45이으. El buen acuerdo general teoría-experimento y las similitudes con el sistema H/HOPG, permiten concluir sobre la escasa o nula influencia del sustrato en este sistema.

Relativo al estudio experimental análogo realizado en protones dispersados por una monocapa de $\mathrm{C}_{60}$ depositado sobre $\mathrm{Cu}(111)$, se obtuvo que: i) las fracciones positivas y negativas son similares en magnitud en todo el rango de energías estudiado, ii) cierta dependencia con la geometría experimental estudiada y iii) no existe una dependencia monótona definida con la energía de incidencia. Estos resultados podrían ser interpretados experimentalmente como 'intermedios' respecto de los dos sistemas previamente descriptos. Comparando estos resultados con los calculados, las tendencias son descriptas satisfactoriamente, especialmente para la geometría 45이으, pero no así la relación entre las magnitudes de las fracciones de iones negativos y positivos en todo el rango de energías analizadas. Resulta evidente que la interacción $\mathrm{C}_{60}-\mathrm{Cu}$ (111) juega un rol significativo en este caso, y la misma debe ser descripta con mayor precisión para explicar adecuadamente los resultados experimentales obtenidos. En lo relacionado a nuestro cálculo, resulta menester considerar otros átomos dispersores de la molécula de $\mathrm{C}_{60}$ ya que se espera que los mismos contribuyan de manera distinta al intercambio de carga con el proyectil, dada las diferencias en las densidades de estado local encontradas.

\section{ABSTRACT}

\section{Falta título en ingles}

The formation of positive/negative ions during the charge exchange in proton collisions with a metal surface of $\mathrm{Cu}(111)$ and different $\mathrm{C}_{60} / \mathrm{Cu}$ (111) films (different thickness) is experimentally and theoretically analyzed. On the experimental side, the LEIS (Low Energy lon Scattering) surface characterization technique was used to determine the charge state of the projectiles after the collision with these target surfaces. A wide range of projectile incident energies and two different collision geometries were analyzed. Regarding the charge transfer experiments in low energy collisions of $\mathrm{H}^{+}$with a thick coating of $\mathrm{C}_{60}$ on $\mathrm{Cu}(111)$, it was found that the percentage of backscattered total ions increases with the energy of incidence and, contrary to what happens in the $\mathrm{H}^{+} / \mathrm{Cu}(111)$ system, the fraction of positive ions is greater 
than that of negatives in practically the entire range of energy studied. The analogous experimental study carried out on protons dispersed by a monolayer of $\mathrm{C}_{60} / \mathrm{Cu}(111)$ results could experimentally be interpreted as 'intermediate' with respect to the two previously described systems.

To gain in the understanding of the physical processes that determine the final charge state of the projectiles after colliding with the surfaces described, theoretical calculations were performed by applying a first-principles based quantum mechanical formalism. The good general agreement between theoretical and experimental is achieved.

The differences between measurements-theoretical results and the analysis of characteristic times in the collision allow us to conclude on the relevance of the projectile entrance path and the fine details of the electronic surface-structure on the studied system. 